This PDF is a selection from a published volume from the National Bureau of Economic Research

Volume Title: Founding Choices: American Economic Policy in the 1790 s

Volume Author/Editor: Douglas Irwin and Richard Sylla, editors

Volume Publisher: University of Chicago Press

Volume ISBN: 0-226-38474-8 (cloth); 0-226-38475-6 (paper)

ISBN13: 978-0-226-38474-0 (cloth); 978-0-226-38475-7 (paper)

Volume URL: http://www.nber.org/books/irwi09-1

Conference Date: May 8-9, 2009

Publication Date: December 2010

Chapter Title: Federal and State Commercial Banking Policy in the Federalist Era and Beyond

Chapter Authors: Howard Bodenhorn

Chapter URL: http://www.nber.org/chapters/c11743

Chapter pages in book: (151 - 176) 


\title{
Federal and State Commercial Banking Policy in the Federalist Era and Beyond
}

\author{
Howard Bodenhorn
}

\subsection{Introduction}

In his study of the development of American law, historian Lawrence Friedman (1993) reminded us that the Bill of Rights applies only to the federal government, not the states. Although the Virginia Declaration of Rights predated the Bill of Rights by thirteen years and provided its philosophical underpinnings, the direction of constitutional influence was from federal to state levels. Many states simply copied the first ten amendments to the federal Constitution when drafting their own. The hypothesis offered here is that the same federal-to-state line of influence is evident in early American banking law and policy. Pennsylvania, Massachusetts, Maryland, and New York chartered banks prior to Congress's charter of the Bank of the United States in 1791. Yet it was the Bank of the United States charter, not that of any of the previously chartered state banks, that served as a model for most subsequent bank charters. The choice to model charters after that of the Bank of the United States rather than those of the early state banks followed from contemporary concerns with political governance, and reflected the outcome of a wider debate about the nature of representative government. In addition, the decision to follow the Bank of the United States model notably influenced how banks were organized, operated, and governed.

Translating federal charters into state law was not seamless, and the debates were charged and rancorous. Although many contemporaries supported

Howard Bodenhorn is professor of economics at Clemson University and a research associate of the National Bureau of Economic Research.

I thank Farley Grubb, Richard Sylla, John Wallis, Eugene White, two anonymous referees, and participants at the NBER Founding Choices Conference for many helpful comments. I also thank Pam Bodenhorn for exceptional research assistance. 
banks and finance, many late-eighteenth- and early-nineteenth-century Americans saw banking as something to be entered into with caution, if at all. Henry Clay, an otherwise ardent spokesman for pro-growth internal improvements such as roads, turnpikes, and canals, was less enthusiastic about banks. During Congressional debate in 1811, Henry Clay labeled the Bank of the United States a "splendid association of favoured individuals invested with exemptions and surrounded by immunities and privilege" (Dorfman 1946, 341). Clay's distaste for the bank sprang not just from a western agrarian's conception of banks as promoters of speculation and sharp dealing; rather, his distaste sprang from a more general view of the corporation as an instrument of oppression capable of robbing the country of its hard-won republicanism. Americans had fought a war to rid itself of aristocratic privilege. Corporations smacked of a return to a government sanction of privilege.

Early American firms were shaped by contemporary social conceptions of appropriate horizontal power relations inside the firm, and the Federalist era bank, as a corporation, was shaped by those conceptions (Lamoreaux 1997; Dunlavy 2006). But, the debate was more fundamental than how partners or shareholders would treat with one another. Contemporary Americans who had no direct stake in the business corporation took great interest in its internal governance because rules for how the elite-and make no mistake about it, the elite controlled America's earliest financial corporations - shared power within the corporate body politic spoke to their attitudes toward sharing power in the wider civic polity.

Incorporating a bank or other business enterprise in the Federalist period was contentious because of different beliefs about the nature of governance. Was governance to be plutocratic or democratic? It was within this debate that the first banks were established and this debate influenced how banks were governed, which ultimately influenced how banks did their business. The political debates surrounding the establishment of the Bank of North America (1782) and the Bank of the United States (1791) defined these banks and nearly every bank chartered thereafter up to the mid-1830s and beyond. Specifically, the liberal Bank of North America charter that imposed few meaningful restrictions on the bank's operation, accountability, or governance gave way to the Bank of the United States' more restrictive charter that sharply limited its operations, made it accountable to government, and defined many of its internal governance procedures. And, as all students of American history are aware, concerns with the role of the corporation within the polity, especially the large corporation, remained unresolved through Jackson's war on the second Bank of the United States, into the progressive era trust-busting, beyond the New Deal reforms, and up to the present. Debates over the establishment of the country's earliest banks cast light on the origins of modern concerns. Ultimately, eighteenth-century Americans wrestled with questions of appropriate internal governance, effective trans- 
parency, and prudent regulation that remain unresolved into the twenty-first century.

This chapter traces four features of the Bank of the United States charter that found their way into many, if not most, state bank charters - charter term limits, partial state ownership, branch banking, and internal voting rules-and how those features influenced banking for the next half-century. Charter term limits and state ownership played havoc with federal and state banking policies because they made banks as much political as economic agents. Branch banking was not widely adopted, but where it was it generally performed fairly well. The advantages of branch banking became most apparent during panics and financial crises as banks and branches could support one another. The adoption of share voting rules that capped the votes of large shareholders encouraged small investors. This choice may have affected the ability of entrepreneurs to raise external capital and, ultimately, the pace of economic growth. Through his influence over the charter of the Bank of the United States, Hamilton's legacy reverberated through the antebellum era and beyond.

\subsection{The Bank of North America: The Debate on Corporate Privilege Is Joined}

The Bank of North America (BONA) was born of crisis. In the spring of 1781, the English army was moving easily through the South. The currency was depreciated to the point of near collapse, Congress had exhausted its fiscal resources, patriotic fervor had given way to frustration, and American morale sank lower by the day. Facing a grave situation, Congress centralized the army and other administrative departments. It also created the office of the superintendent of finance and appointed Robert Morris to the post. The new superintendent was the second most powerful figure in the reorganized government, second only to George Washington, and was granted almost complete control over fiscal policy (Rappaport 1970).

Morris entered his post with a sweeping vision of fiscal reform (Riesman 1987). Morris' public finance plan featured a bank as its centerpiece, a bank that was to provide assistance during the war and contribute to the country's postwar prosperity. ${ }^{1}$ Rappaport $(1970,1996)$ contended that Morris unveiled his banking plan so quickly after assuming office that he must have contemplated it long before. We know that Hamilton, while still a member of Washington's staff, twice wrote to Morris with bank proposals. But Morris thought Hamilton's schemes too bold, too audacious - one called for a

1. Morris originally believed that the BONA's profits would be sufficient to retire the Congressional debt, and envisioned refunding the debt and financing it through a sinking fund made up of the bank's profits. Riesman $(1987,144)$ argues that Morris formulated this plan after reading the work of the English Whig Richard Price, who in 1772 formulated a comparable plan for extinguishing Britain's massive debt. 
bank of $\$ 200$ million capital — and proposed a more modest institution. Morris's plan called for a bank with just $\$ 400,000$ in capital, divided into $\$ 400$ shares. The difference between Hamilton and Morris on the bank was that Hamilton envisioned a bank as an arm of government that might serve commercial interests; Morris envisioned the bank as an arm of commerce that might serve the government. It did not occur to Morris that the government would own shares, perhaps because the government was effectively bankrupt, and more in need of capital than a supplier of it.

Congress chartered the bank on 31 December 1781, but lingering concerns over whether it actually had the power to do so led it to ask states to enact similar supporting legislation (Lewis 1882). Massachusetts, Rhode Island, Connecticut, New York, New Jersey, and North Carolina all passed enabling legislation. It was not until Morris petitioned the Pennsylvania legislature for a charter that serious concerns were raised. Critics feared the consequences of the original grant's concession of a perpetual charter and its right to amass up to $\$ 10$ million in assets. The latter was troublesome because it held the potential for the establishment of a "monied aristocracy"; the former was equally troublesome because a perpetual charter placed the institution beyond subsequent legislative control. Neither argument gained traction and the bank received its charter.

Except for the profits earned in its early years, the BONA did not become noteworthy until 1785 , when the bank's operations and its charter provoked a larger debate over the meaning of democracy and the corporation's place within it. In September 1785, less than four years after Congress had chartered it, the Pennsylvania Assembly repealed the bank's charter.

What had the bank done to turn the Assembly against it? To many legislators the better question was what hadn't the bank done. Hammond (1957, 53) listed the sundry charges leveled against the bank: it encouraged usury; it refused to lend on long terms to farmers; it refused to lend on mortgage security, again, to farmers; it insisted on punctuality in meeting one's debts to the bank; it allowed foreigners (which included not only Europeans, but individuals from neighboring states) to invest in the bank; and, it demonstrated favoritism toward certain borrowers, mostly shareholders. The bank's real sins, however, were its opposition to the chartering of a rival institution, its opposition to the state's emission of $£ 100,000$ in bills of credit, its refusal to accept notes issued by a $£ 50,000$ loan office, or land bank and, above all, its adoption of high-pressure lobbying practices against all three otherwise popular (and populist) measures.

Morris was quick to defend his bank and denied that its agents' actions in any way undermined democratic institutions. But his arguments failed to sway many critics because he was also quick to point out that it had been established on the idea that it could lend to whomever it saw fit. Reisman $(1987,148)$ observed that Morris was blind "to charges that the bank was a monopoly favoring some and not others" and he failed to grasp 
why others cared so deeply about the larger issues raised by the bank and its practices.

Care they did, and deeply, too. Although the bank's critics provided a laundry list of the bank's transgressions, many of which were fallacious, the legislative committee recommending the annulment of the bank's charter stated "that the accumulation of enormous wealth in the hands of a society who claim perpetual duration, will necessarily produce a degree of influence and power, which cannot be entrusted in the hands of any one sett [sic] of men whatsoever, without endangering the public safety" (Carey 1786, 52). Further, the bank, which was envisioned by Congress as an arm of government, was no longer dependent on that government, and thus without an effective check on its operations. ${ }^{2}$ Because the bank's president, Thomas Willing, and other officers and supporters, including Morris, failed to take the legislature's annulment threat seriously, few arguments in support of the bank were offered until the matter was all but decided. The breadth of opposition to the bank took its supporters by surprise. The vote to annul was lopsided as legislators from every region of the state, including Philadelphia, voted against the bank. Outside the legislature, criticism came from all quarters. Farmers and mechanics opposed it because it confined its loans to mercantile firms. Mercantile firms on whom the bank did not bestow its favors opposed it for its favoritism.

The ink on the act annulling the charter was barely dry before plans to have the charter restored were put in motion. The election of Robert Morris and two of the bank's other directors to the Assembly, coincident with a mass petitioning campaign asking for reinstatement of the charter guaranteed that the issue would be revisited. Transcripts of the legislative debates offer a window into contemporary attitudes about republican government and whether it could survive economic and financial modernization. The foundational political disagreement centered not on favoritism in lending or the bank's opposition to a state loan office and the emission of bills of credit, but on the internal governance of the bank, which reflected wider concerns with the nature of republican governance writ large. If the corporation was, as Samuel Blodgett insisted, a "moneyed commonwealth" within a commonwealth, a "moneyed republic" within a republic, then the nature of corporate governance reflected on the possibilities and the pitfalls of political governance. ${ }^{3}$

What were the governance features inside the bank that so offended republican sensibilities? Two features of the bank's internal operations-one share-one vote and the absence of any mechanism to ensure the rotation in office for directors-became recurring themes of the debate. Assemblymen

2. The federal government had repaid its large loans to the bank by selling off the interest it took when Morris subscribed to $\$ 254,000$ in stock on its behalf.

3. Blodgett is quoted in Dorfman $(1946,338)$. 
Lollar and Smilie attacked the one share-one vote rule directly because it concentrated power, a practice that Smilie argued was "highly dangerous" because it would inevitably lead to "direct tyranny" by the large shareholders over the small (Carey 1786, 109). He raised the rhetoric further by drawing an analogy between the bank and the wider polity, asking whether members of the assembly would ever agree to vest power in any similarly small group of men through a voting rule that allocated votes by wealth. ${ }^{4}$

Greater wealth did not establish a basis for multiple votes in the polity, so there was no reason for it to do so within the corporation. Voting power determined by wealth, in fact, was likely to spill over into the polity. William Findlay, skilled debater, western Republican, lover of large beaver hats, and vocal opponent of the bank, provided an alarming vision of proportional voting rules. Liberal corporate charters, like that given the bank, created not little republics but "little aristocracies" that would ultimately "engross all the wealth, power, and influence of the state," and if made large enough would first monopolize land holding, then trade, and finally the government itself (Carey 1786, 66-9).

The failure of the bank's charter or bylaws to establish a system of rotation among the directors also smacked of privilege and aristocracy. It conjured up a vision of aristocrats with permanent, powerful positions. Even more troubling was that it conjured a "vision of placemen and tax gatherers [or, in this case, usurers] swarming the countryside . . . to support wealthy men in high places" (Reisman 1987, 157). Moreover, without established term limits "the bank will remain under the present directors, during their lives, which is a direct tyranny" (Carey 1786, 109).

In his defense of the bank, Robert Morris dismissed Republican concerns as "bugaboo" (Carey 1786, 58). Instead of allaying fears of concentrated power, he celebrated it. It might be true that the directors of the bank remained in office for long periods and were elected by "six or seven men, largely concerned in stock," but how else might it be? Would it be right for those with small numbers of shares to have power equal to those with many? "Voting according to property," Morris asserted, "is the only proper mode of election" (Carey 1786, 117). If the legislature was to tamper with the proportional voting rule inside the corporation, it may as well pass an agrarian law-contemporary code words for radical mass reallocation of land from rich to poor-and divide all property equally. Such would be the tyranny of

4. It is ironic that legislators voted into office by the fraction of the potential electorate who met the property requirement for voting spoke against voting rights allocated by wealth. It was the case, of course, that once a man met the property requirement, he received only one vote regardless of how many times over he satisfied the requirement. I thank Eugene White for pointing this out. Harris (2009) reported that it was the charter of the English East Indies company that established the one shareholder-one vote rule. It was only later that the voting rule was altered. The original Bank of England charter also imposed a one shareholder-one vote rule (Redlich 1968). Redlich argued that Americans were aware of the Bank of England rule and purposely adopted an alternative. 
the small shareholders over the large and, ultimately, the poor over the rich. So Morris, too, believed the debate over internal corporate governance was about something deeper and more fundamental than corporate governance per se. If corporate governance, as constituted in the BONA charter at least, was a mirror in which to view the potentialities of republican governance generally, Morris liked what he saw inside the bank; his opponents feared it.

The BONA's proponents carried the day. The act repealing the charter was itself repealed, but the legislature imposed several new restrictions on the bank, among them a fourteen-year charter, and stricter limits on the amount and type of assets it might hold, most notably a restriction on land ownership except what was needed to operate the bank. The new charter did not overturn the one share-one vote rule, but under pressure the bank's shareholders adopted a bylaw that established an upper limit on the number of votes a single shareholder could cast.

To modern sensibilities, the late-eighteenth-century debate over the corporation seems a tempest in a teapot. To contemporaries, however, the concern was very real. Historians note contemporary beliefs that republics were inherently fragile. The risks were so great and the prospect of failure so ever present, that the institutions of modernity, including the corporation and all it represented, spelled its eventual but certain doom (Lewis 1993, 117). The modern conception of representative democracy as one in which multiple interest groups vie with one another in shaping policy had not yet revealed itself to late-eighteenth-century politicians, Federalist no. 10 notwithstanding. Most Americans, including those in power or aspiring to it, whether Federalist or Republican, believed in a "unitary, definable public good and common purpose that could be discerned and articulated by virtuous and selfless men" (Sharp 1993, 89). This approach became what later historians labeled the politics of the absolute, or the belief that there was a single, definable objective and that dissent emerged not from a legitimate and alternate view of the public good, but from a desire to undermine the republic and subvert the constitution (Elkins and McKitrick 1993).

An appreciation of the political debates of the 1780s matters because only in understanding it can later state banking policies be understood. Although modern political parties had not yet emerged by the time the original thirteen states started chartering banks, the battle lines were already sharply drawn. What would later be labeled "Federalist" or "Republican" found expression in the Pennsylvania debates transcribed by Carey. Moreover, Carey's decision to publish the transcripts put the debate on the national stage and provided the foundational arguments for two or three subsequent generations of banking proponents and critics alike. When Sullivan (1792) attacked the Massachusetts Bank, he expressed many of the same concerns in the same terms as those raised in the BONA debates. Like the revisions to the BONA charter in 1786, the Massachusetts Bank's charter was amended in 1792 in an attempt to place more effective limits on its corporate powers. That same 
year Massachusetts incorporated the Union Bank, the charter of which can only be read as a legislative attempt to balance the growing demand for commercial banking with democratic principles. Instead of dividing the Union Bank's capital stock into $\$ 400$ (par) shares, as it had done with the Massachusetts Bank, its $\$ 800,000$ capital was divided into $\$ 8$ (par) shares to disperse shareholding as widely as possible. It was an everyman's bank and, therefore, neither as prone to insider favoritism nor as dire a threat to the republic.

\subsection{Alexander Hamilton, the Bank of the United States, and Early State Banking Policy}

Like Morris a decade earlier, when Hamilton assumed leadership of the Treasury, he was bedeviled by three questions of public finance: How would the government raise revenues? How would the government raise funds in anticipation of future revenues? And how would it transfer funds from the place of collection to the place of disbursement? Hamilton's answers comprised the three pillars of the Federalist financial revolution (Sylla 1998). Hamilton's plan included, among other features, the Bank of the United States (BUS).

Hamilton produced a number of documents in support of his plan, but it was his Report on the Bank that is considered groundbreaking (Cowen 2000; Wright and Cowen 2006), and it reveals a cognizance of the 1785 BONA debates. His Report did not represent Hamilton's first thinking about a bank. He had previously corresponded with Robert Morris about the desirability of a national bank, and he was the principal author of the Bank of New York's 1784 articles of association (Hammond 1957, Redlich 1968), several features of which found expression in the BUS charter.

Hamilton's plan for the bank began with a discussion of what the bank should not be. First, it should not be a land or mortgage bank. It was important that the national bank be a specie-based commercial bank that could realize and liquidate its assets promptly. Second, it should not be a wholly state-owned bank. Hamilton understood the importance of private interest and believed that the profit motive should guide its operations. Nevertheless, it was imperative that the government was a part owner so that it could receive dividends and exercise some direction or management. Third, the bank should not be without supervision. A vital element of Hamilton's plan was that some officer of the state, preferably the treasury secretary, should retain the right to conduct inquiries and inspect its books (Clarke and Hall 1832, 30).

The features of the 1791 BUS charter are provided in table 5.1, and can be usefully divided into general provisions, regulations, and governance rules. The general provisions include features such as the capitalization and share value described in Section 1, how, when, and where the shares would be 


\section{Charter section}

1

2

3

4

5

6
Provisions of the Bank of the United States charter (1791)

\section{$\$ 10$ million capital in $\$ 400$ shares.}

Individual subscriptions limited to 1,000 shares. Shares payable-1/4 in specie, $3 / 4$ in $6 \%$ federal bonds-in four installments.

Bank granted corporate powers for 20 years and may hold up to $\$ 15$ million in real and personal property.

Bank governed by 25 directors subject to annual reelection. President to be chosen from among the elected directors.

Bank may commence as soon as $\$ 400,000$ in capital is paid in.

Directors have power to appoint managers and determine managerial compensation.

Prudent mean voting rule for shareholders. Only shareholders resident in United States could vote by proxy.

Only $3 / 4$ of existing directors eligible for reelection.

Directors must be shareholders.

Directors will not be paid for services unless specifically approved by shareholders.

Board quorum is 7 directors.

Any 60 stockholders with a combined 200 shares could call a special meeting of stockholders.

Officers required to post performance bonds.

Bank may only own so much land as required for the conduct of business or that surrendered in judgment.

Bank's debts (banknotes) may not exceed $\$ 10$ million. Directors are personally liable for any excess.

Bank may sell any of the public debt used to purchase shares, but it cannot buy additional bonds. Its trade will be limited to bills of exchange and specie. Interest charges limited to $6 \%$.

Loans to state, federal, or foreign governments limited without express Congressional consent.

Stock transferrable by rules adopted by directors.

Debts signed by president and countersigned by cashier are negotiable and transferable.

Semiannual dividends payable from profits at discretion of directors.

Branch offices may be opened wherever directors see fit.

Secretary of treasury may inspect the bank's books at any time, not more often than once each week.

All officers and directors who trade or authorize trade in goods not allowed by charter are subject to treble damages.

All officers and directors who loan or authorize loans to governments in amounts in excess of limits are subject to treble damages.

Bank's notes are receivable for all debts to United States.

President of the United States may, at his discretion, subscribe to onefifth of the bank's stock. The bank shall loan the amount to the government.

No other bank will be chartered by Congress during the term of the 20-year charter.

Sources: Hamilton's Report reprinted in Clarke and Hall (1832, 21-32). Bank of the United States charter reprinted in Holdsworth and Dewey (1910, 126-32). 
subscribed and paid for (\$2), the time limit of the charter (\$3), the reservation of shares for the government ( $\$ 11)$, and the promise to not charter a competing bank for the duration of the BUS's charter (\$12). Regulatory provisions included such features as Section 7.8, which forbade the bank from trading in real estate, Section 7.9 that limited its banknote issues, Section 7.10 that restricted its dealings in public debt, as well as Sections 8 and 9 that prescribed punishments for violations of these restrictions. Finally, and perhaps, most importantly, the charter included several conditions - found mostly in Sections 4 and 7 - that established internal governance procedures for the bank. Internal governance rules, as was evident in the BONA debates, not only affected shareholders and managers, but influenced the perceptions of outsiders.

The BUS charter became the model that many legislatures followed in drafting state bank charters and, therefore, shaped the contractual relationship between hundreds of banks and the states in which they operated. ${ }^{5}$ The nature of these contracts determined how well banks performed their intermediation functions and how they responded (or failed to respond) to contemporary political and economic circumstances. This is not to diminish the BUS as an important agent of treasury's fiscal policy or independent monetary policy. Those features of the BUS have been explored elsewhere (Holdsworth and Dewey 1910; Timberlake 1978; Kaplan 1999; Sylla, Wright, and Cowen 2009). What is less well appreciated is the fundamental role the BUS - and by implication Hamilton - played in shaping state banking policy up to the adoption of free banking by several states after 1837 .

The extent to which the BUS charter influenced state bank policy becomes evident in table 5.2, which lists twenty-five features of the BUS charter and their appearance in the charters of four banks organized prior to the establishment of the BUS in 1791, and four banks chartered thereafter. Some variant of the most basic general provisions appear in the earliest bank charters (or articles of association), including the total capital, the number of shares, and the grant of corporate status. Few restrictions appear in the pre-1791 charters. It is particularly notable that the earliest bank organizers imposed relatively few internal governance rules on themselves. Compared to the BUS charter, the governance rules were a patchwork and tended to the innocuous, such as the requirement that directors stand for annual reelection. It is notable that not one of the pre-BUS banks afforded shareholders the right to call extraordinary meetings. Of course, banks might provide some of the governance features not included in their charters through bylaws or other internal operating rules, but bylaws provided a lesser guarantee that

5. Redlich $(1968,21)$ recognized this fact when he wrote: "the tendency to model charters of newer banks on those of certain older ones led to integration. In fact some bank charters became models to whole groups of banks in the same state and even elsewhere." Redlich was correct, but he failed to trace the influence back to the BUS charter and how it shaped state banking policy, or how it influenced financial sector performance. 


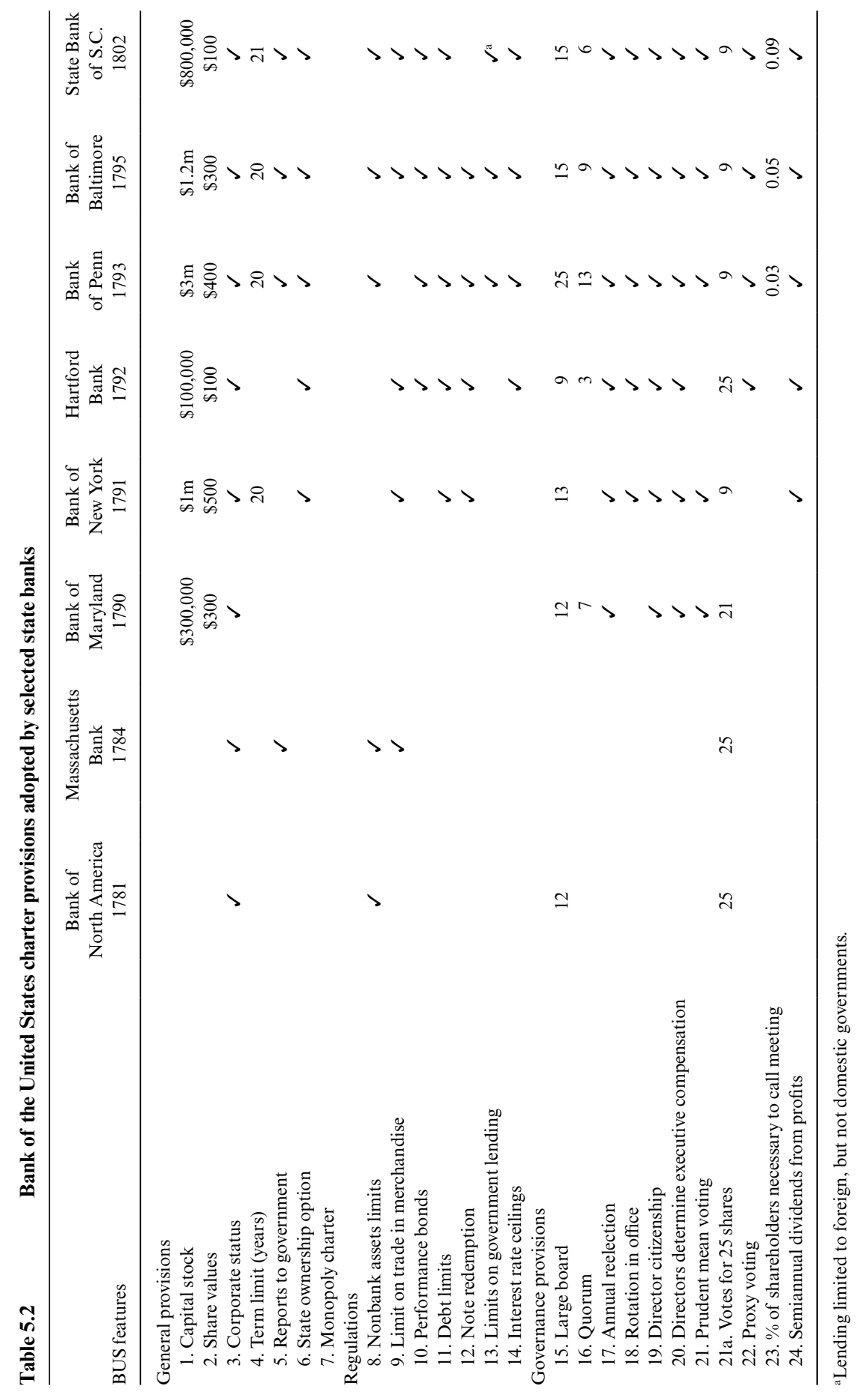


investors would ever realize a return on their investment (Shleifer and Vishny 1997). Directors might change bylaws whenever they no longer suited the directors' purposes so that, compared to explicit charter provisions, internal rules were a second-best guarantee of shareholder rights.

The influence of the BUS charter on state banking policy becomes apparent when we consider the charters of post-BUS banks. Although the banks listed in table 5.2 were not randomly selected, they are indicative of the wide and long-lasting influence of the BUS charter. Nearly every charter imposed a time limit, required regular reports of condition to the government, and reserved some shares for the state. Every legislature reserved the right, most implicitly, to charter other banks. There are similar commonalities between the BUS and the state banks in the restrictions placed on banks' activities and in the basic corporate governance rules.

\subsection{Hamilton's Legacy in the Near- and Long-Term}

This section discusses the consequences of four notable features of the BONA debate and the BUS charter that influenced later charters: charter time limits, branch banking, government ownership, and prudent mean voting rules. In 1791, United States policymakers stood at a crossroads where they could adopt BONA-style charters or BUS-style charters. In the main, they opted for the BUS form, and that choice had notable long-term consequences. The following paragraphs illuminate the practical effects of those choices on financial stability and bank ownership.

\subsubsection{Charter Time Limits}

It is notable that, in his twenty-four point plan for a bank in his Report, Hamilton accepted a de facto term limit for the BUS (Clarke and Hall $1832,31)$, when earlier in the document he dismissed the suggestion that the BONA become the national bank because in accepting its Pennsylvania charter it had "rendered [itself] a mere bank of a particular state, liable to dissolution at the expiration of fourteen years" (26). That it faced the prospect of another contentious rechartering debate in 1800 rendered the BONA unfit to be a national bank.

Why did legislatures impose term limits on banks? At least three reasons, two philosophical and one practical, present themselves. First, under the theory that a charter represented an inviolable contract between a state and a corporation, a perpetual charter was troublesome because it placed the corporation beyond effective legislative control. John Taylor of Caroline was not alone in his conviction that a corporation might hide behind its charter, outlive its original purpose, and threaten the republic (Conkin 1980, 65). ${ }^{6}$

6. The famous Dartmouth College case (Trustees of Dartmouth College v. Woodward, 4 Wheaton [1819]) had not yet been decided. In Dartmouth College, the Supreme Court of the 
Second, a related though distinct objection to a perpetual charter is summarized in Jeffersopn's oft-quoted phrase that "the Earth belongs in usufruct to the living" (Sloan 1993). A fundamental tenet of contemporary Republican political philosophy held that each generation owed to its successors the freedom to make their own choices. Because it was easier to renew good laws than repeal bad ones, it was imperative that laws be written with limited duration. Even bad laws have a constituency, Jefferson observed. Automatic expiration approximately every twenty years would limit the pernicious effects of bad laws. ${ }^{7}$ A third, more pragmatic, reason for charter term limits reflected the states' ongoing search for sources of revenue and the discovery by state assemblies that not only were prospective bankers were willing to pay for new charters, but existing bankers would pay for the renewal of existing charters (Schwartz 1947). Charter renewal generated income for state treasuries as banks were forced to pay, sometimes handsomely, to extend their charters. ${ }^{8}$

The most consequential legacy of charter time limits was that rechartering debates were often more rancorous and politically charged than the original chartering debates; so much so, in fact, that rechartering efforts sometimes failed. It is ironic that Hamilton's bank fell prey to the very concerns he expressed over transforming the BONA into a national bank - that the term limit on its charter made it susceptible to political intrigue and, ultimately, closure. Although its charter did not expire until 1811, the bank's proponents unsuccessfully initiated the recharter process in 1808. Although treasury secretary Albert Gallatin recommended recharter, the House bill was defeated 65 to 64, while the Senate deadlocked at 17 to 17 until Vice President Clinton, a political enemy of both Madison and Gallatin, cast the deciding negative vote (Cowen 2008).

Of the thirty-nine recorded congressional speeches on recharter, thirtyfive revisited the constitutionality of the bank (Clarke and Hall 1832). Hammond (1957) questions the sincerity of these statements given that Jefferson and Madison's original constitutional concerns had been allayed by 1811 and Gallatin himself, once a foe of the bank, expressed confidence in it and

United States held that corporate grants were protected under the contract clause of the federal Constitution. Once granted, governments had limited power to amend charters. After Dartmouth, many states introduced clauses into bank charters that reserved the right of the state to amend them.

7. It is notable that Madison was less enthusiastic about regular rewriting of laws than Jefferson. Madison, in fact, viewed the prospect of rewriting laws every nineteen years with alarm (Sloan 1993, 300; see Madison to Jefferson, 4 February 1790). The difference in approach between the two probably reflects Madison's pragmatism born of his more extensive legislative experience. It was also the case that some present improvements were of sufficient magnitude that it was efficient to burden future generations with some of their costs.

8. In 1830 the Bank of Pennsylvania was required to lend the state $\$ 4$ million at below-market rates to assist the state's ongoing canal building project. It was also forced to accept responsibility for maintaining the transfer books for the state debt, an uncompensated service that cost the bank an estimated $\$ 9,000$ per year over the next two decades (Holdsworth 1928, 148-50). 
lauded its utility to treasury operations. Others objected to foreign ownership, suggesting that British ownership of the bank undermined American republicanism. But this argument, too, was specious because foreign owners could not vote their shares and had little say in the bank's management. The BUS's most outspoken supporters were city bankers who made use of the BUS's branches to facilitate interregional remittances and recognized that it might serve as a lender of last resort in a crisis. Most state banks, however, were pleased with the BUS's demise because it meant the shuttering of its clearing and collection functions, which had served as a check on their own lending and note issues. The bottom line: because Hamilton succumbed to pressures to include a charter term limit, the bank was forced to close not from malfeasance, mismanagement, or misfortune, but rather from partisan motivations.

The mistake was repeated in the charter of the Second Bank of the United States and in a multitude of state bank charters. The story of President Andrew Jackson's war on the Second Bank of the United States is now so well known that it does not bear repeating here, but the twenty-year term limit written into the 1816 charter meant that the Second Bank's survival hung on whether the bank's supporters and, ultimately, its leader-Nicholas Biddle - might bargain with Jackson over the terms of the recharter (Hammond 1957; Schlesinger 1946). Neither Biddle nor Jackson was willing to compromise, and the war between these two mighty personalities resulted in the closing of a proto-central bank whose presence under Biddle's leadership may have mitigated the financial effects of the panic of 1837 (Temin 1969). A similar drama, albeit on a smaller stage, was replayed in Indiana in the early 1850s. A charter limit-induced political battle between free banking Democrats and more regulatory minded Whigs ended with the closing of the State Bank of Indiana, one the Old Northwest's best-managed banks (Esary 1912). One legacy, then, of the BUS charter was charter term limits. Such term limits, no matter how philosophically justified or expedient, generated unwarranted economic dislocations.

\subsubsection{State Ownership}

In reserving one-fifth of the shares of the BUS for itself, the federal government became the largest residual claimant to the profits of the country's single largest enterprise. Several states followed suit. Virginia, for example, subscribed to shares in the Bank of Virginia, whose charter was modeled closely after the BUS charter. North Carolina and Kentucky later followed Virginia's example. In taking a direct ownership stake, the state ensured that it received a share of a bank's profits. It also provided the state with some say, through the appointment of directors, over the operations of the bank. Finally, if the state needed to borrow money, legislators believed that it might borrow more readily and on better terms from a bank in which it was a part owner (Esary 1912). 
State ownership, established in Hamilton's Report as a fundamental mechanism of corporate governance, was not viewed by all contemporaries as desirable. Some believed that "there was no evil more to be dreaded, except war and pestilence, than a connection between government and banking" (Esary 1912, 267), and John M. Felder of South Carolina spoke of the "vile concubinage of banks and state" (Klebaner 1990, 42). Despite such concerns, by 1812 a majority of the states owned some bank stock; some states already did, or soon would, charter wholly state-owned banks. ${ }^{9}$

State-owned enterprises are typically justified in that they will correct a market failure and are expected to improve resource allocation and overall welfare (Atkinson and Stiglitz 1980). An alternative view holds that stateowned enterprises are created by politicians to pursue the goals and interests of politicians, not the community at large (Shleifer and Vishny 1994). If they fall under political control, state-owned enterprises become sources of inefficiency because they (mis)allocate resources to favored groups. The evidence on state ownership of banks in modern economies is not positive. State ownership is associated with lower rates of productivity and economic growth, less efficient private finance, greater credit risk and lower management efficiency, and lending not to credit constrained but to politically connected firms (La Porta, Lopez-de-Silanes, and Shleifer 2002; Sapienza 2004; Cornett et al. 2010).

Berg and Haber (2009), however, argue that the manifold problems that have emerged with state-owned enterprises, especially among banks in the twentieth century, may not have been as severe in the nineteenth century. The U.S. experience is best described as mixed. Vermont, for example, chartered a state-owned bank in 1806. By the time it was closed in 1812, it had suffered $\$ 200,000$ (\$3.7 billion in 2008 dollars) in losses and land owners paid additional assessments to reimburse creditors (Klebaner 1990; Root 1895). State-owned banks also failed, with significant losses to creditors, in Alabama, Georgia, Tennessee, and Illinois (see table 5.3).

Hamilton, of course, did not propose full state ownership; he proposed that the government take a 20 percent stake. But 20 percent may have been enough to establish effective control over the board, which rendered even those banks with less than 100 percent state ownership state banks (La Porta, Lopez-de-Silanes, and Shleifer 1999). The evidence in table 5.3 on the partly state-owned banks is not easily summarized either. Virginia's early experience may be indicative of the pitfalls surrounding mixed public and private banks. Chartered in 1804 and organized in 1805, it quickly became clear that the legislature was determined to exercise as much control over the Bank of Virginia (whose charter is as close to a copy of the BUS charter as any) as possible. Under the bank's charter, the state could vote all 3,000 of its

9. Dividends arising from these holdings, as well as bank taxes, represented a significant share of state revenues (Sylla, Legler, and Wallis 1987). 
Table 5.3 Selected experiences with state bank ownership

\begin{tabular}{|c|c|c|c|c|}
\hline State & Years & $\begin{array}{c}\text { State } \\
\text { ownership } \\
(\%)\end{array}$ & Failed & Notes \\
\hline Maryland & $1790-$ & 15 & $\mathrm{~N}$ & $\begin{array}{l}\text { Profitable, but required support of transportation } \\
\text { infrastructure and banks generated low returns } \\
\text { to shareholders. }\end{array}$ \\
\hline Pennsylvania & $1793-1857$ & 20 & $\mathrm{Y}$ & $\begin{array}{l}\text { Bank of Pennsylvania profitable until asked to } \\
\text { bail out state investments in Main Line Canal. }\end{array}$ \\
\hline Virginia & $1804-1865$ & 20 & $\mathrm{~N}$ & Profitable, well managed; state divested in $1850 \mathrm{~s}$. \\
\hline Vermont & $1806-1811$ & 100 & $\mathrm{Y}$ & Land tax assessment to repay creditors. \\
\hline Kentucky & $1806-1821$ & 20 & $\mathrm{Y}$ & Undermined by state policies. \\
\hline Delaware & $1807-$ & 20 & $\mathrm{~N}$ & Independent of state intervention, profitable. \\
\hline North Carolina & $1810-1835$ & 20 & $\mathrm{Y}$ & Cotton speculation soured and led to bankruptcy. \\
\hline South Carolina & $1812-1870$ & 100 & $\mathrm{~N}$ & $\begin{array}{l}\text { Profitable, focused on agricultural lending and } \\
\text { avoided competition with private commercial } \\
\text { banks. }\end{array}$ \\
\hline Indiana & $1816-1821$ & 37 & $\mathrm{Y}$ & Poor management led to charter revocation. \\
\hline Mississippi & $1818-$ & 50 & $\mathrm{Y}$ & $\begin{array}{l}\text { Finances undermined by state's railroad } \\
\text { investments. }\end{array}$ \\
\hline Tennessee & $1820-1832$ & 100 & $\mathrm{Y}$ & Taxpayers reimbursed bank's creditors. \\
\hline Illinois & $1821-1824$ & 100 & $\mathrm{Y}$ & Poorly managed and failed quickly. \\
\hline Alabama & $1823-$ & 100 & $\mathrm{Y}$ & Taxpayers reimbursed bank's creditors. \\
\hline Georgia & $1828-$ & 100 & $\mathrm{Y}$ & $\begin{array}{l}\text { State lost "large amount"; taxpayers reimbursed } \\
\text { bank's creditors. }\end{array}$ \\
\hline North Carolina & $1833-1863$ & 40 & $\mathrm{~N}$ & Not well regarded by contemporaries. \\
\hline Indiana & $1834-1857$ & 50 & $\mathrm{~N}$ & Profitable, well regarded, charter not renewed. \\
\hline Missouri & $1837-$ & 50 & $\mathrm{~N}$ & Profitable, well managed. \\
\hline Tennessee & $1838-1868$ & 100 & $\mathrm{~N}$ & $\begin{array}{l}\text { Bank returned dividend to state, but struggled } \\
\text { underwriting state railroad investments. }\end{array}$ \\
\hline
\end{tabular}

Sources: Root (1895); Starnes (1931); Duke (1895); Bryan (1899); Holdsworth (1928).

shares while the maximum number of votes afforded any other shareholder was limited to thirty. Additionally, the state treasurer was an ex officio member of the board. Thus, the state wielded inordinate power over the board.

In early January 1805 , the Republican-dominated state assembly adopted, by a 124 to 14 vote, a resolution instructing the state treasurer to "procure a compleat $[\mathrm{sic}]$ preponderance of persons of sound [R]epublican principles" (Enquirer 1805) to the bank's board. The resolution, in fact, instructed the treasurer to ensure that the fourteen-member board of the Richmond branch have at least ten Republicans and that each thirteen-member board of the branches have nine Republicans. In the 1805 board elections, the state cast 3,000 of 5,107 ballots (even though it owned only 20 percent of the shares) and, not surprisingly, each branch had either nine or ten Republican directors. It is notable that in August 1805 the bank's share prices were depressed, and one newspaper attributed the low prices to shareholder uncertainty over the consequences of partisan boards. Despite the politicized nature of the 
bank's boards in its early days, the Bank of Virginia established a strong dividend record and survived to the Civil War (Starnes 1931).

No systematic inquiry into the performance of state-owned banks in the nineteenth century United States exists, but if the modern record is indicative, the likelihood that they were a net benefit is low. On the other hand, evidence on failure rates implies that no easy conclusion can be drawn without a deeper understanding of the legal and political constraints under which each bank operated in each state. A handful of success stories in the nineteenth century certainly counters the charge that state-owned institutions are inherently flawed. The available evidence and existing interpretations are not inconsistent with the possiblity that economies in the early stages of development, such as Indiana, Tennessee, and Missouri circa 1835, faced some market failure that a well-run state bank mitigated.

\subsubsection{Branch Banking}

Alexander Hamilton was not of a single mind in his remarks on branching in the Report. At one point, he contended that branching was problematic and best avoided, but later in the document he remarked on the utility of branches. These statements were probably less symptomatic of inconsistency of thought than imprecision in expression: Hamilton favored branches, but only once the BUS was established and had developed the internal controls and managerial capabilities necessary to keep them in check. But if Hamilton was of two minds on branch banking, he was not alone among his contemporaries and several subesequent generations of United States bankers. Branch banking never gained a foothold in New England or the Mid-Atlantic region. Ironically, branch banking took hold and prospered south and west of Maryland, the home states of those Republicans most opposed to the size and scope granted the BUS in its charter.

Branch banking was attractive in the South and Old Northwest because large branch banks consolidated small, scattered pools of capital that may have been invested in undercapitalized financial institutions in the absence of larger, often state-sponsored branch banks. When scattered pools of private capital were supplemented with direct state investment, public confidence in many of these banks was enhanced, fears of "vile concubinage" notwithstanding. Confidence in the banks' abilities to meet their obligations encouraged the use of bank money, which reinforced the banks' intermediary abilities and encouraged the spread of the market. To the extent that developed, functioning markets are public goods, state sponsorship of banks in regions not yet fully within the orbit of such markets was an instance of state-sponsored enterprises solving a market failure (Friedman 2005).

One common justification for branch banking is that it provides opportunities for portfolio diversification, hence stability, unavailable to unit banks. Given the underlying economies of the states in which branch banking emerged - Virginia, North and South Carolina, Kentucky, Tennessee, 
Ohio, and Indiana - it is not clear that branch banking facilitated anything other than geographic diversification. These were not economies with notable manufacturing, and even the mercantile sector was small compared to that in New England and the Mid-Atlantic. The fortunes of these banks was heavily dependent on shipments of cotton, grain, and other primary products. Bad weather and bad prices led to bad loans, no matter how the loans were spread among the branches.

The real advantage of branch banking in the antebellum South and West - interbank cooperation - became apparent in crises. Intrabank and interbank cooperation arose among branch banks during the panics of 1837 and 1857 (Bodenhorn 2003; Calomiris and Schweikart 1991). During the panic of 1837, for example, Kentucky's branch banks labored to maintain specie payments after their correspondents in Philadelphia and New Orleans had suspended them. Surprisingly, two of the state's largest banks - the Bank of Kentucky and the Northern Bank of Kentucky - were able to maintain their pre-panic levels of loans and circulation through the summer of 1837, even while they increased their specie holdings. When the Northern Bank was run in August 1837, it met the specie calls and survived the run mostly because its rival, the Bank of Kentucky, came to its aid. Interbank lending increased sharply in late summer 1837, and the Kentucky branch banks weathered the panic about as well as any state's system.

The State Bank of Ohio's branch and mutual guarantee features also allowed that system to survive the panic of 1857 , even though the banks were heavy creditors of the failed Ohio Life Insurance and Trust Company. The State Bank avoided suspension and failure because its mutually insured branches cooperated with one another during the panic. Although the State Bank of Ohio was not a branch bank in the traditional sense, they formed a federation of banks under a common supervisory and regulatory board. Each bank was autonomously managed, but each was proportionately responsible for the liabilities of the thirty other members, which provided each with an incentive to monitor the actions of all others in good times. In a panic, this structure created incentives to assist others facing a run. During the panic, in fact, stronger banks supplied reserves to weaker or vulnerable banks. None of the State Bank's members failed, compared to the failure of nearly half of neighboring Indiana's independent banks.

Hammond (1957) commended Canadians for adopting charters closely modeled on that of Hamilton's BUS, charters that included the right to establish branches. Unlike the United States, where branching was confined to the less economically developed regions, branching in Canada was ubiquitous. In this feature, at least, "the handiwork of Alexander Hamilton . . . survives still in the Dominion [of Canada]" (Hammond 1957, 662). Although the Canadians embraced branch banking at the expense of oligopoly, the citizenry benefitted from greater stability and many fewer failures during panics and recessions (Bordo, Rockoff, and Redish 1994). It is well known 
that no Canadian bank failed during the Great Depression, though thousands of branches were closed. Branch closings, however, were not as destabilizing as bank failures.

Some of the states that followed Hamilton's lead and adopted branch banking in the nineteenth century anticipated the Canadian experience in that they reaped the benefits of greater stability and paid the costs of modestly higher interest rates (Bodenhorn and Rockoff 1992). Was the trade-off welfare enhancing? Consider the Indiana experience. When the branched State Bank of Indiana dominated in the early 1850s, borrowers were charged interest rates about 1.4 percentage points higher than borrowers in New York City (Bodenhorn and Rockoff 1992, 177). The State Bank had about $\$ 1$ million in outstanding loans at any time in the early 1850 s and the state had 988,000 inhabitants. If the bank's loans turned over about 2.5 times per year, the annual per capita interest rate costs of market power amounted to 3.6 cents. When the State Bank's charter lapsed and it was replaced by free banks, an average of two failed each year with annual losses of nearly $\$ 80,000$ (Economopoulos 1988). With 1.35 million inhabitants in 1860, the annual per capita loss due to bank failure was 5.9 cents. For Indiana in the late antebellum era, at least, the cost of bank instability exceeded the cost of bank monopoly, unless the deadweight losses of monopoly exceeded the deadweight losses of instability-induced reduced money holdings. Branch banking, then, provided several benefits to bank customers, the most notable of which was greater stability. It is unclear whether Hamilton considered this a likely outcome, but it was certainly a valuable by-product.

\subsubsection{Voting Rules}

Voting rights, especially how votes would be cast and by whom, represented a critical governance feature outlined in the Report and in the BUS charter. Hamilton's Report and the BUS charter had three important voting rights clauses. First, foreign shareholders were excluded from voting their shares and exercising any direct control rights. Foreigners retained residual claims to profits, but were unable to influence management, at least through their voting power. "Due caution," wrote Hamilton, was called for in order to "guard against a foreign influence insinuating itself" into the bank (Clarke and Hall 1832, 28).

Second, item 11 of the Report recommended proxy voting. Hamilton recognized that liberal voting rights assured stockholders that managers could not substantially modify the terms of the stockholders' investment without their consent. Liberal voting rights limited managerial discretion and protected against expropriation (Baums 1997; La Porta et al. 1998). Of course, occasions might arise when substantial modifications to the charter contract might benefit stockholders, so gaining their consent was vital. Because shareholding was geographically dispersed and transportation costly, shareholder meetings at which corporate policy might be renegoti- 
ated would be prohibitively costly to organize and mediate. Proxy voting reduced the costs of gaining majority consent and effecting change in corporate policy. Charter clauses allowing proxy voting are missing from all pre-1792 charters. After the clause is included in the BUS charter, it becomes ubiquitous in state bank charters. In this instance, the BUS influence on state banking policy is unmistakable.

A system of voting rights that Hamilton labeled the "prudent mean" represented the third important governance feature included in the BUS charter that found its way into several state banking systems. The BONA debates highlighted the gravity with which contemporaries viewed corporate voting. "Like civic governance," wrote Dunlavy (2006), "corporate governance has many dimensions, but there are good reasons to single out voting rights as its foundation" (1354). Dunlavy (2006) classified voting rights along a continuum from "plutocratic" (one share-one vote) to "democratic" (one shareholder-one vote), with all manner of variation in between. Hamilton labeled one point along the continuum the "prudent mean," which he defined with the following voting rule:

For one share, and not more than two shares, one vote; for every two shares above two, and not exceeding ten, one vote; for every four shares above ten, and not exceeding thirty, one vote; for every six shares above thirty, and not exceeding sixty, one vote; for every eight shares above sixty, and not exceeding one hundred, one vote; and for every ten shares above one hundred, one vote; but no person, co-partnership, or body politic, shall be entitled to a greater number than thirty votes. (Clarke and Hall $1832,32)$

Hamilton offered his prudent mean voting rule because he considered the one share-one vote rule adopted by the BONA "improper" and the one shareholder-one vote rule "not less erroneous" (Clarke and Hall 1832, 28).

The plutocratic rule of one share-one vote increased the likelihood that a few stockholders might take control of the bank and direct its resources to their advantage and to the detriment of minority shareholders. Concentration of about 20 percent of shares appears sufficient to take control of a modern corporation, and given the communication and transportation network circa 1800, 20 percent was surely enough to take effective control (La Porta, Lopez-de-Silanes, and Shleifer 1999). It was on this issue that Morris and Hamilton's visions of proper corporate governance diverged. In the BONA debates, Morris adamantly defended one share-one vote rules as the only available mechanism to protect large shareholders from the depredations of the minority. Hamilton was not only more concerned about the ability of large shareholders to subvert the corporation to the detriment of minority shareholders, but about political appearances. In advocating a prudent mean voting rule, Hamilton successfully walked a 
tightrope: he simultaneously undermined political objections to plutocratic voting rules, protected minority shareholders by affording them disproportionately large voting representation, and still encouraged large bloc investment by offering larger shareholders a greater measure of control over the bank's operations than a democratic one shareholder-one vote rule would have afforded.

Although one share-one vote rules were common by the end of the nineteenth century (Morris's view ultimately prevailed), at the beginning of the century most Americans remained wary of power vested with large shareholders under one share-one vote rules and, instead, adopted rules more akin to Hamilton's prudent mean (Dunlavy 2006). Lines 21 and 21a in table 5.2, again, reveal BUS influence on American corporate governance, at least for the first half of the nineteenth century. None of the pre-BUS charters adopted a prudent mean-type rule. Many, but not all banks, adopted it thereafter. As a measure of the limits placed on large stockholders, line 21a reports the number of votes a stockholder holding twenty-five shares was allowed to cast at a stockholder's meeting. While the Hartford Bank adopted the one share-one vote rule, the other banks adopted rules that gave a shareholder with twenty-five shares only nine votes - the same rule imposed on stockholders in the BUS. Variations quickly appeared: stockholders with twenty-five shares could cast eight votes at shareholder meetings in New Jersey, ten votes at meetings in New Hampshire, eleven votes in Ohio, twelve or thirteen in Missouri, but only six in Georgia. Connecticut developed no hard and fast rule, but rather responded to the organizers' wishes. Only two of the first ten banks chartered in Connecticut adopted prudent mean voting rules. The other eight adopted one share-one vote rules.

That some states adopted prudent mean voting while others adopted one share-one vote rules affords an opportunity to determine whether the prudent mean rule had any meaningful effect on shareholding. State bank commissioners occasionally published the names and shareholdings of bank shareholders in the antebellum era. These records were combined with voting rules included in bank charters. Data on sixty-nine banks from five states (Connecticut, Maine, New York, Pennsylvania, and Wisconsin) between the 1830s and 1850s show that the average concentration ratio for the twenty largest shareholdings (i.e., CR-20) was 0.79 . That is, the twenty largest shareholders owned nearly 80 percent of the outstanding shares of the sample banks. The Herfindahl-Hirshman index (HHI) of share ownership was $1355 .{ }^{10}$ The CR-20 and HHI values suggest fairly concentrated

10. The Herfindahl-Hirschman Index $\left[(\mathrm{HHI})=(1,000) \cdot \Sigma s_{i}^{2}\right]$ can assume any value between 0 and 10,000. A value of 10,000 implies ownership by one shareholder. A value approaching 0 implies completely atomized ownership. The HHI values for the range between 75 and 10,000, and the standard deviation is 1,756 . 
bank share ownership: the mean of the sample was $\$ 125,000$ in paid-in capital owned by sixty-seven shareholders. ${ }^{11}$

To better understand the association between the dispersion of share ownership and prudent mean voting rules, I regressed shareholder concentration measures against a prudent mean indicator variable, in addition to measures of the bank's age (more time for shares to either disperse or concentrate), nominal capital stock (larger banks had more available shares), and state dummy variables. The estimated coefficient on the prudent mean indicator coefficient when regressed on CR-20 was -0.24 ( $t$-statistic $=5.80 ; p<0.001)$, which implies that the twenty largest shareholders owned approximately one-fourth less of the outstanding shares of banks with prudent mean voting rules compared to banks with one share-one vote rules. When CR-20 was replaced with the HHI as the dependent variable, the coefficient on the prudent mean indicator variable was $-216.4(t$-statistic $=1.7 ; p<0.10)$. At the mean HHI a prudent mean voting rule reduced share owner concentration by about 12 percent of the standard deviation in HHI.

The sample is too small and the estimating technique too crude to draw causal inferences, but the size and significance of the association suggests that early nineteenth-century minority bank shareholders were concerned with majority shareholder expropriation. Minority shareholdings were much more common and represented a larger fraction of bank ownership when charters limited large shareholder control through prudent mean voting rules. More research is required, but the results suggest that if the organizers' principal concern was raising outside capital, they might prefer a prudent mean share voting rule to encourage dispersed ownership. If the organizers' principal concern was retaining control of the bank, they probably preferred a one share-one vote rule.

The corporate governance issues surrounding voting rules run deeper than horizontal power relations inside the firm, however. Although large bloc shareholding might improve managerial performance because large shareholders had greater incentives to monitor, nineteenth-century Americans also recognized that large bloc holdings come at a cost: large shareholders might adopt rules or policies that disadvantage or expropriate from small shareholders (Shleifer and Vishny 1986; Holderness and Sheehan 2000). It remains to be determined whether dispersed ownership, encouraged by prudent mean voting rules, or more concentrated ownership, encouraged by one share-one vote rules, resulted in more profitable, more prudent, more stable banks.

11. Using the turnover of shares as a proxy for dispersion of ownership, Wright (1999) concludes that shares were widely dispersed. The concentration ratios at points in time suggest otherwise. Of course, there is no consensus on the values of the various concentration measures that separate concentrated from dispersed ownership. Minguez-Vera and Martin-Ugedo (2007) contend that an average HHI of 1,500 for the modern Spanish publicly traded corporation is high, especially when compared to an average HHI of 570 for the modern British publicly traded corporation (Trojanowski and Renneboog 2002). 


\subsection{Conclusion}

It is historically inaccurate to think about Federalist banking policy as a clearly articulated set of objectives, statutes, and administrative regulations. Federalist banking policy was an attitude and a loosely constructed approach to the establishment of, and control over, financial intermediaries. The clearest statement of that approach is found in Hamilton's Report on a National Bank and in the charter of the Bank of the United States. These were the documents that defined two generations of the contract between states and their banks. Although Hamilton was a student of history, as were many of his contemporaries, he had limited guidance in how to construct a bank and almost no guidance in constructing a system. It is clear that the Bank of England charter influenced Federalist approaches to banking (Andréadès 1909), but the politicians and the bankers of the time were making up much of the script as they went along.

This is not to say that the Federalists did not impose some structure on their banks, which later developed into a banking system. They imposed structure and order through the charters they granted. Federal policies became state policies because state legislators had the same concerns as the founders about the relationship between business and government and adopted the BUS charter as a model in creating state systems. It was an organic process and the model evolved over time, of course, but the Bank of the United States' DNA remains evident in state bank charters several generations removed from the 1791 original.

\section{References}

Andréadès, A. 1909. History of the Bank of England. Translated by Christabel Meredith. London: P.S. King \& Son.

Atkinson, A. B., and J. E. Stiglitz. 1980. Lectures on public economics. London: McGraw Hill.

Baums, T. 1997. Shareholder representation and proxy voting in the European Union: A comparative study. Max Planck Institute. Working Paper.

Berg, A., and S. Haber. 2009. Always turkeys? Brazil's state owned banks in historical perspective. Stanford University. Working Paper.

Bodenhorn, H. 2003. State banking in early America: A new economic history. New York and Oxford: Oxford University Press.

Bodenhorn, H., and H. Rockoff. 1992. Regional interest rates in antebellum America. In Strategic factors in nineteenth century American economic history: A volume to honor Robert W. Fogel, ed. C. Goldin and H. Rockoff, 159-87. Chicago: University of Chicago Press.

Bordo, M. D., H. Rockoff, and A. Redish. 1994. The U.S. banking system from a northern exposure: Stability versus efficiency. Journal of Economic History 54 (2): $325-41$. 
Bryan, A. C. 1899. History of state banking in Maryland. Baltimore, MD: Johns Hopkins University Press.

Calomiris, C., and L. Schweikart. 1991. The panic of 1857: Origins, transmission, and containment. Journal of Economic History 51 (4): 807-34.

Carey, M. 1786. Debates and proceedings of the general assembly of Pennsylvania: On the memorials praying for a repeal or suspension of the law annulling the charter of the Bank. Philadelphia: Seddon \& Pritchard.

Clarke, M., and D. A. Hall. 1832. Legislative and documentary history of the Bank of the United States. Washington, DC: Gales \& Seaton.

Conkin, P. K. 1980. Prophets of prosperity: America's first political economists. Bloomington: Indiana University Press.

Cornett, M. M., L. Guo, S. Khaksari, and H. Tehranian. 2010. The impact of state ownership on performance differences in privately-owned versus state-owned banks: An international comparison. Journal of Financial Intermediation 19: 74-94.

Cowen, D. 2000. The origins and economic impact of the first bank of the United States, 1791-1797. New York and London: Garland Publishing, Inc.

- 2008. First Bank of the United States. EH.Net Encyclopedia. Ed. R. Whaples. Available at: http://eh.net/encyclopedia/article/cowen.banking.first_bank.us.

Dorfman, J. 1946. The economic mind in American civilization, 1606-1865. New York: Viking Press.

Duke, B. W. 1895. History of the Bank of Kentucky, 1792-1895. Louisville: John P. Morton \& Co.

Dunlavy, C. 2006. Social conceptions of the corporation: Insight from the history of shareholder voting rights. Washington \& Lee Law Review 63:1347-88.

Economopoulos, A. J. 1988. Illinois free banking experience. Journal of Money, Credit and Banking 20 (2): 249-64.

Elkins, S., and E. McKitrick. 1993. The age of Federalism. New York: Oxford University Press.

Enquirer. 1805 (January 8). Richmond, Virginia.

Esary, L. 1912. State banking in Indiana, 1814-1873. Bloomington, IN: Indiana University Bulletin, vol. 10, no. 2.

Friedman, B. M. 2005. The moral consequences of economic growth. New York: Vintage Books.

Friedman, L. 1993. Crime and punishment in American history. New York: Basic Books.

Hammond, B. 1957. Banks and politics from the Revolution to the Civil War. Princeton, NJ: Princeton University Press.

Harris, R. 2009. Law, finance and the first corporations. In Global perspectives on the rule of law. Ed. J. J. Heckman, R. L. Nelson, and L. Cabatingan, 145-72. Abingdon: Routledge-Cavendish.

Holderness, C. G., and D. P. Sheehan. 2000. Constraints on large-block shareholders. In Concentrated corporate ownership, ed. R. K. Morck, 139-75. Chicago and London: University of Chicago Press.

Holdsworth, J. T. 1928. Financing an empire: History of banking in Pennsylvania. Chicago and Philadelphia: S. J. Clarke Publishing Company.

Holdsworth, J. T., and D. R. Dewey. 1910. The first and second Banks of the United States. Washington, DC: Government Printing Office.

Kaplan, E. S. 1999. The Bank of the United States and the American economy. Westport, CT and London: Greenwood Press.

Klebaner, B. J. 1990. American commercial banking: A history. Boston: Twayne Publishers. 
Lamoreaux, N. 1997. The partnership of organization: Its popularity in earlynineteenth-century Boston. In Entrepreneurs: The Boston business community, 1700-1850, ed. C. E. Wright, and K. P. Viens, 269-95. Boston: Massachusetts History Society.

La Porta, R., F. Lopez-de-Silanes, and A. Shleifer. 1999. Corporate governance around the world. Journal of Finance 54 (2): 471-517.

- 2002. Government ownership of banks. Journal of Finance 57:265-301.

La Porta, R., F. Lopez-de-Silanes, A. Shleifer, and R. W. Vishny. 1998. Law and finance. Journal of Political Economy 106 (6): 1113-55.

Lewis, J. 1993. "The blessings of domestic society": Thomas Jefferson's family and the transformation of American politics. In Jeffersonian legacies, ed. P. S. Onuf, 109-46. Charlottesville: University Press of Virginia.

Lewis, L., Jr. 1882. A history of the Bank of North America: The first bank chartered in the United States. Philadelphia: J. B. Lippincott \& Company.

Minguez-Vera, A., and J. F. Martin-Ugedo. 2007. Does ownership structure affect value? A panel data analysis for the Spanish market. International Review of Financial Analysis 16 (1): 81-98.

Rappaport, G. D. 1970. The sources and early development of the hostility to banks in early American thought. PhD diss. New York University.

- 1996. Stability and change in revolutionary Pennsylvania: Banking, politics, and social structure. University Park: Pennsylvania State University Press.

Redlich, F. 1968. Molding of American banking. New York: Johnson Reprint Company.

Riesman, J. A. 1987. Money, credit, and Federalist political economy. In Beyond confederation: Origins of the Constitution and American national identity, ed. R. Beeman, S. Botein, and E. C. Carter II, 128-61. Chapel Hill: University of North Carolina Press for the Institute of Early American History.

Root, L. C. 1895. States as bankers. Sound currency 2 (10): 221-52.

Sapienza, P. 2004. The efefcts of government owenership on bank lending. Journal of Financial Economics 72:357-84.

Schwartz, A. J. 1947. The beginnings of competitive banking in Philadelphia, 17821809. Journal of Political Economy 55 (5): 417-31.

Sharp, J. R. 1993. American politics in the early republic: The new nation in crisis. New Haven, CT and London: Yale University Press.

Shleifer, A., and R. Vishny. 1986. Large shareholders and corporate control. Journal of Political Economy 94:461-88.

. 1994. Politicians and firms. Quarterly Journal of Economics 109 (4): 9951025.

- 1997. A survey of corporate governance. Journal of Finance 52 (2): 737-83.

Schlesinger, A. M., Jr. 1946. The age of Jackson. Boston: Little Brown.

Sloan, H. 1993. "The Earth belongs in usufruct to the living." In Jeffersonian legacies, ed. P. S. Onuf, 281-316. Charlottesville: University Press of Virginia.

Starnes, G. T. 1931. Sixty years of branch banking in Virginia. New York: Macmillan.

Sullivan, J. 1792. The path to riches: An inquiry into the origins and use of money; and into the principles of stocks and banks. Boston: P. Edes.

Sylla, R. 1998. U.S. securities markets and the banking system, 1790-1840. Review 1998 (May): 83-98.

Sylla, R., J. B. Legler, and J. J. Wallis. 1987. Banks and state public finance in the new republic: The United States, 1790-1860. Journal of Economic History 47 (2): $391-413$.

Sylla, R., R. E. Wright, and D. J. Cowen. 2009. Alexander Hamilton, central banker: 
Crisis management during the U.S. financial panic of 1792. Business History Review 83:61-86.

Temin, P. 1969. The Jacksonian economy. New York: W.W. Norton \& Co.

Timberlake, R. H., Jr. 1978. The origins of central banking in the United States. Cambridge and London: Harvard University Press.

Trojanowski, G., and L. Renneboog. 2002. The managerial labor market and the governance role of shareholders control structures. Social Science Research Network. Working Paper. Available at: http://papers.ssrn.com.

Wright, R. E. 1999. Bank ownership and lending patterns in New York and Pennsylvania, 1781-1831. Business History Review 73 (1): 40-60.

Wright, R. E., and D. J. Cowen. 2006. Financial founding fathers: The men who Made America rich. Chicago: University of Chicago Press. 